\title{
NEWS AGENCIES IN THE SERVICE OF STATE PROPAGANDA IN POLAND, YUGOSLAVIA AND BULGARIA DURING THE 1930s*
}

\begin{abstract}
Based on primary sources and relevant literature the organization and role of news agencies in state propaganda in Poland, Yugoslavia and Bulgaria during the 1930s will be analyzed. Special attention will be paid to similarities and differences between the agencies.
\end{abstract}

Key words: News agencies, BTA, Avala Agency, PAT, Poland, Yugoslavia, Bulgaria, propaganda

A news agency is basically a group of journalists, established to supply news organizations (newspapers, magazines and radio) with news. The first agencies were formed in the first half of the nineteenth century. The oldest news agency was established in France in 1835 by a Parisian translator and advertising agent, Charles-Louis Havas as Agence Havas. Two of his employees, Bernhard Wolff and Paul Julius Reuter, later set up rival news agencies bearing their last names in Berlin (1849) and London (1851) respectively. In 1853, in Turin, Guglielmo Stefani formed the Agenzia Stefani and this became the most important agency in the Kingdom of Italy and the set example was soon followed by the other countries and agencies. ${ }^{1}$

* This article was written as part of scientific project: Tradition and transformation historical heritage and national identities in Serbia in the 20th century (№ 47019), which has been financed by Ministry of Education and Science of Republic of Serbia.

1 Chronologically the second world wide agency was the American Associated Press established in 1848 . 
Literature about news agencies in Poland, Yugoslavia and Bulgaria in the Interwar period is rather limited. Only few titles considering general history of agencies has been written for the period in question. ${ }^{2}$ This fact is mainly due to a lack of sources (especially for cases of Yugoslavia and Bulgaria). This paper is a small contribution to the subject and call for further research. Before analyses of three countries under review one should examine the situation on the general European level.

\section{News agencies in Europe in the 1930s}

Over the years, news agencies became increasingly important and thus became more attractive to the governments. Generally in Europe in the 1930s, one could find three different systems of relations between the news agencies and states:

1) The system of free press, where all telegraph agencies were private, some were subsidized by the government and had their own correspondents and special envoys in the publishing houses. Central government offices, which were adjunct to the Ministries of Foreign Affairs only, had limited direct contact with the agencies. This applied to countries such as France, England, USA and Belgium.

2) The system of controlled press in which the agencies operated as semi-governmental official agencies and their correspondents were located in major capital cities. The government authorities had impact on the press and this system was implemented by such countries as Romania, Hungary and Turkey.

3) The system of directed press in which the institutions of news agencies were subordinated to press discipline exercised by the government and ruling parties. Members of the ruling circles were officials in the agencies and the agencies were instruments in the hands of the government. This was the case in the countries such as Italy, Germany, Soviet Union and Spain.

2 W. Grabowski, Polska Agencja Telegraficzna 1918-1991 [Polish Telegraph Agency 1918-1991], (Warsaw, 2005); E. Rudzinski, Informacyjne agencje prasowe w Polsce 1926-1939 [Press Informational Agencies in Poland 1926-1939], (Warsaw, 1970); 100 години Бьгарска телеграфска агенция [100 Years of Bulgarian Telegraph Agency], (Sofia, 1998); Б. Симић, „Агенција 'Авала" [Avala Agency], Зборник Матице српске за историју, број 75-76/2007, Нови Сад, 75-91. 
Over the years, news agencies began to cooperate with one another and it was necessary to define their obligations more precisely. In the late 1920 s and in the 1930s, there were as many as thirty news agencies, in as many countries and these functioned as an unofficial World League of Press Associations for the exchange of news. Most of them were European countries except for the USA, Canada, Japan and China. ${ }^{3}$ The majority of the countries represented in the world alliance had one or more news agencies in addition to their main agency, e.g. Great Britain had seven and Italy four other agencies. ${ }^{4}$ The exceptions were the smallest countries or countries where agencies were made official or semi-official.

Initially, each agency was restricted to the sale of news entirely in its own country or in defined territories. At the London meeting in 1932 of the representatives of Reuters, Associated Press, Havas and Wolff ${ }^{5}$ agency, that arrangement was liberalized and any one of the agencies was permitted to sell its services independently to any newspaper or other clients wanting it in a country normally served by one of the other member agencies. ${ }^{6}$

The four biggest agencies had arranged coverage for most of the world in the following way, with the exchange of news among them: Associated Press - United States, Central America and South America in co-operation with Havas; Reuters - Great Britain and the British Colonies, the Netherlands, the Far East and Near East in co-operation with Havas; Havas - France, the French Colonies, Romanic countries

3 Members of the World League of Press Associations were: Amtliche Nachrichtenstelle (Austria), Agence Télégrapique Belge (Belgium), Bulgarska Telegrafska Agenciya (Bulgaria), Canadian Press, Ltd (Canada), Reuters, Branch of British Agency (China), Československa Tisková Kancelá (Czechoslovakia), Ritzaus Bureau (Denmark), Eesti Telegraafi Agentuur A. S. (Estonia), Finska Notisbyran (Finland), Agence Havas (France), Deutsches Nachrichten Büro G.m.b.h (Germany), Reuters, Ltd. (Great Britain), Agence d'Athènes (Greece), Magyar Távirati Iroda (Hungary), Agenzia Stefani (Italy), Domei Tsushin Sha (Japan), Latvijas Telegrafa Agentura (Latvia), Agence Télégraphique Lithuanienne (Lithuania), Algemeen Nederlandsch Persbureau (Netherlands), Norske Telegrambyr (Norway), Polska Agencja Telegraficzna (Poland), Agence Havas, Branch of French Agency (Portugal), Agence Orient Radio (Romania), Telegrafnoje Agentstwo Ssojusa, TASS (Soviet Union), Agencia Telegrafica Fabra (Spain), Tidningarnas Telegrambyr (Sweden), Agence Télégraphique Suisse (Switzerland), Anodolu Ajansi (Turkey), Associated Press (U.S.A), Agencija Avala (Yugoslavia).

4 Other British agencies were: British United Press Ltd, Central News Ltd, The Central Press Ltd, Exchange Telegraph Co. Ltd, Press Association Ltd, British Continental Press, London General Press and Italian were: Agenzia di Roma, Agenzia Volta, Agenzia Telegrafica Orientale, Radio Nazionale.

5 Wolff became known in 1933 as the Deutsches Nachrichten Büro (DNB).

6 R. Desmond, The Press and World Affairs, (New York, 1937), p. 68. 
of Europe, South America in the co-operation with the Associated Press and Near East in co-operation with Reuters; DNB - Germany and Austria. ${ }^{7}$

The majority of news agencies in the 1930s Europe were official or semi-official. The classic examples of official agencies were in Germany, Italy and the Soviet Union. In those countries, opposition or unwelcome views almost never received any publicity unless it suited the regime's propaganda purposes as the news agencies were in fact agencies of those governments. The situation with the semi-official agencies was a bit different but in many cases, it was not that diverse from the official ones. Most of the semi-official news agencies were tied to a government and subsidized by them.

All news agencies at some point co-operated with the government out of national loyalty. Even agencies that were declared as independent were at least partly propaganda organizations. The agencies on occasion received exclusive news releases from their governments and in return, they provided the governments with advance copies of incoming foreign dispatches before distribution. This sometimes gave governments the opportunity to revise dispatches in accord with the official viewpoint and, in some cases, to withhold the news completely until a time that seemed more suitable for its release. ${ }^{8}$

\section{Establishment of news agencies in Poland, Bulgaria and Yugoslavia and their early years}

Of three countries under review the first to found the news agency was Bulgaria. The organization of Bulgarian state propaganda started as early as the nineteenth century while the country was still under the rule of the Ottoman Empire. One of the key steps in that direction was the establishment of the Bulgarian Telegraphic Agency (BTA) in 1898 and this was founded by the decree of King Ferdinand. Initially, it was only the agency for delivering telegrams about events abroad and the first bulletin was published on $16^{\text {th }}$ February. In the early years BTA was based on the model of the Russian Petersburg Telegraph Agency and unlike most news agencies at the time, which were private, BTA had the status of a special department within the Ministry of Foreign Affairs

\footnotetext{
7 Ibid.

8 Ibid, pp. 73-74.
} 
and Religions (MVRI). In the period in question, the head of the Office was the experienced journalist I. Herbst. The associates were young educated people who excelled in their command of foreign languages. ${ }^{9}$

In the beginning, its purpose was to provide the Bulgarian media with information on domestic and international events. Most of the news dealt with events taking place at European royal courts, crime, trade and message exchange. In addition, the Agency provided information on events in the country to foreign telegraph agencies. Initially, there were only five employees: director, his deputy, press clerk plus two collaborators in the technical area. ${ }^{10}$

After the First World War, BTA signed new contracts with the most important news agencies like Havas, Reuters, Wolf and Stefani. The main tasks in that period was: to maintain contact with Europe's largest agencies, to protect the Bulgarian national cause abroad, to fight against negative foreign propaganda about Bulgaria and to inform the foreign press about the situation in the country. ${ }^{11}$

The situation in BTA in the late 1920s was not satisfactory. Some concerns were expressed in a note written by the Press director in December 1929 as director Ivan Popov urged for the separation of BTA and to formally make it a private agency on commercial grounds with the aim to improve its role in state propaganda. Besides the obvious, Popov stated one other reason: „Especially for one small and weak country like ours, this is of great importance, because, when a telegraph agency is official, the responsibility for all its telegrams which are unfavorable for some countries lies with the official government..."12 At the end of the passage, Popov asked a very inmportant question: "How many times has BTA missed an opportunity to publish some interesting and useful news because it was unpleasant for this or that neighboring country! Is this a weakness?"13 From the point of view of state propaganda, this was a valid point. At the time in Europe, state propaganda tasks were becoming increasingly more demanding and

9 И. Илчев, Родината ми права или не [My Real Motherland or Not], (Sofia, 1995), p. 148.

10 Бьлгарските дьржавни институции 1879-1986 [Bulgarian State Institutions 1879-1986], (Sofia, 1987), рр. 38-39.

11 Ibid.

12 Архив на Бьлгарска телеграфна агенция [Archive of Bulgarian Telegraph Agency] (BTA), box 1, Справки за БТА, материяли за БТА..., Из докладна записка на директора на печата до главни секретар на Министерство на Вьшните работи [From the note of director for the Press addressed to secretary general of Ministry of Foreign Affairs], p. 2.

13 Ibid. 
complicated and the official news agencies were always marked and sometimes treated with distrust. Nevertheless, Bulgaria did not follow the proposed measures and remained one of the countries with a state news agency during the Interwar period.

The Yugoslav Avala Agency was formed in September 1919 after the founding of Yugoslavia (at that time known as the Kingdome of Serbs, Croats and Slovenes). Initially, French journalist Albert Mousset was in charge of this organization ${ }^{14}$ and he was a friend of King Aleksandar Karadjordjević. He remained in this position until 1927 when he left under suspicious circumstances. ${ }^{15}$ From 1920, the agency began to receive news from some European capitals (Paris, Bern, Athens, Madrid) and began to develop its network of international correspondents. In the first phase of its development, Avala was subordinated to the Press Office of the Ministry of Foreign Affairs and French was the official language of the agency.

In the late 1920s, the news agency in Yugoslavia, as in Bulgaria, started to lag behind the leading European agencies and this was expressed in the letter written in 1929 which urged for the necessary changes in the work of Avala, the report described the situation in the agency in the late 1920s:

"As an official agency, Agency Avala is not capable of satisfying the all the needs of modern journalism, and even less so in the service of state propaganda. This agency is at the bottom, while other agencies, even officials, have their statutes and programs, agency Avala does not have a statute, program, and no specified duties. Agency Avala is, because of poor expertise and slow control of its work, doomed to be late with the news and this is why other agencies are often unsatisfied with its work." 16

14 Albert Mousset (Paris, 1883-1975) was a journalist and historian. In 1908, he completed his studies at the School for Archives. He was a librarian trainee at the Ministry of Foreign Affairs, Secretary of the Committee for the publication of documents relating to the origins of the war of 1870-1871 and in charge of courses at the L'école des Hautes études hispaniques, attached to the Embassy of France in Madrid. In addition, he was the founder and editor of the magazine Affaires étrangères (Foreign Affairs).

15 According to the Yugoslav writer Vuk Dragović, Mousset maintained some relations with the French military and one letter considering that matter was found. $B$. Драговић, Српска штампа између два рата, Основа за библиографију српске периодике 1915-1945 [Serbian Press Between Two Wars, Basis for Bibliography of Serbian Press], (Belgrade, 1956), p. 380.

16 Arhiv Jugoslavije [Archive of Yugoslavia], (AY), Personal Collection of Vojislav Jovanovic Marambo (335), box 74. 
Remarks made in this letter were not far from the truth. The reorganization of Avala began in June 1929 when the agency left the jurisdiction of the Press Department of the Ministry of Foreign Affairs and become a joint-stock company with capital of 5 million dinars. The state bought the vast majority of stocks, 9,540 out of a possible 10,000. Others were bought by the administration of the biggest newspapers in Yugoslavia. ${ }^{17}$ The reorganization was not an easy task. The contract between the state and the agency was signed in May 1930 and the first payment was made in April 1930. ${ }^{18}$ The contract regulated relations and proscribed obligations between them and the first four articles stated the obligations of Avala:

1) To provide information and journalistic services regarding the general public interest of the state;

2) To publish official declarations, to send them to newspapers in the country and abroad,

3) To publish denials of all writings harmful to the interests of the state, with the right to underline its jurisdiction whilst doing it;

4) To deliver its bulletins to the government members, free of charge. ${ }^{19}$

The most important obligation of the state was to pay five million dinars to the agency for the costs of its operations. The contract was signed for five years with the automatic renewal for another five if one of the parties chose not to cancel it. The work manual of the Avala agency defined the structure and functions of the company. It is interesting to note that the contract was signed on the government's behalf by Milan Marjanović, chief of the Central Press-Bureau (CPB), the unofficial Ministry of Propaganda. ${ }^{20}$ This fact only underlined the importance of Avala for state propaganda.

The central propaganda institutions were closely connected even when the Yugoslav agency Avala ceased to operate under the authority of the Office for the Press of the Ministry of Foreign Affairs and became a joint-stock company in June 1929. However, this transformation was regarded more as a formal than as a real one as the state owned

17 Најновија фаза у развоју Агенције Авала [The Newest Phase in Development of Avala Agency], (Belgrade, 1937), p. 7.

18 Ibid, Until $1^{\text {st }}$ April 1930, the Agency managed to spend 3,750,000 dinars of the original capital invested by the state.

19 AY, 37-75-37, The Contract Between the Yugoslav State and Avala Agency A.D.

20 More on CPB see: Б. Симић, Пропаганда Милана Стојадиновића [Milan Stojadinovic's Propaganda], (Belgrade, 2007), pp. 79-103. 
more than $90 \%$ of the overall stocks. ${ }^{21}$ The cooperation of the Agency with the CPB was, in the words of its general manager at the time, "extensive" and "harmonic". 22

The Polish Telegraph Agency (Polska Agencja Telegraficzna, PAT) was founded in December 1918, shortly after the new state was proclaimed as the last of the three agencies. The agency was to be subordinated to the Council of Ministers as an official press and news agency.

According to the regulations, the main tasks of the agency were:

1) Informing the Polish society on all forms of political, social, cultural and economic development; both at home and abroad, and providing reliable foreign news about Polish affairs;

2) Posting their own bulletins and being an exclusive agent for posting official publication toll, non-commercial institutions and state enterprises, or acting under government control in all national and international journals, as well as the exclusive placement of advertisements in all kinds of the above-mentioned state institutions through posters, ads, film, photography, etc.

3) The exclusive agency in making films and photos of buildings of the premises and offices and state institutions on state properties. ${ }^{23}$

To achieve the following goals, PAT used different methods, the most important of which was the publishing of daily bulletins with information. It is difficult to present a full range of editorial activities because of the large number of changes during this period. From the beginning the Polish agency was bigger in size compared to other two which was understandable because Poland was country with more than 30 million people while Yugoslavia had 15 and Bulgaria only 6 million inhabitants.

\section{The structure and duties of agencies during the 1930s}

At this time in Europe, state propaganda tasks were becoming increasingly more demanding and complicated and the official news

21 Најновија фаза..., р. 6.

22 Ibid, Извештај директора Агенције Авала Светислава Петровића из 1937. године [The Report of the Director of "Avala" Agency, Svetislav Petrovic, from 1937].

23 Archiwum Akt Nowych [Archive of Modern Documents], (AAN), PRM, 33-5, Letter of the director Starzynski from June 1930. 
agencies were always labeled and sometimes treated with distrust. In 1930, BTA was one of the three sections of the Press Department, together with the sections for the Press and Documentation. One positive step was made when the self-writing radio receiving set "Hal" was obtained in 1932. Those sets were rented from agencies like Reuters, Havas, GTA and Stefani. The Press Department was renamed the "Press Section" and it functioned within the framework of Ministry of Foreign Affairs with three separate departments - BTA, Press and Information and Documentation where the number of employers varied from 16 to 39 people. ${ }^{24}$

After the coup d'état in 1934, official censorship was introduced which was reflected by the short existence of Censors Committee within BTA. ${ }^{25}$ In 1936, BTA was reorganized again where the Press Office was re-established with three sections - the BTA, Press Service and Information and Documentation and the only formal change was the renaming of the Documentation section into "Information and Documentation".

The final structure of the Press Office and its obligations were set by the Book of Regulations from 1937, which organized the division into:

1) Secreteriat;

2) Department for Information and Documentation;

3) Press Department

4) BTA.

Institutions with this structure existed until the fall of the Monarchy in September 1944 and the number of employees increased to $77 .{ }^{26}$ All sections, BTA included, reported to director of the Press Office. He reported to the Minister of Foreign and Religious Affairs for more important issues and carried out the orders given by the minister. The director maintained contact between the ministry and local press and gave information to the foreign correspondents in Bulgaria.

The new Book of Regulations issued in July 1937 regulated the position and the tasks of BTA (articles 21 to 31). According to the first article referring to BTA, its tasks were: to notify government, press and subscribers about the situation abroad, to spread news from Bulgaria

24 И. Калчева, Бьлгарска телеграфна агенция (1898-1944) [Bulgarian Telegraph Agency 1898-1944], unpublished BA thesis from Faculty of Journalism, (Sofia, 1975), p. 54.

25 Ibid, p. 56.

26 Бьлгарските дьржавни институции..., р. 39. 
through foreign news agencies and with its own correspondents and state consulates, and to give economic and financial news to its subscribers. ${ }^{27}$ The main obligation of BTA was to usually publish three bulletins per day, at 13,19 and one hour after midnight. These bulletins were in Bulgarian and French. In the holiday period, its numbers were reduced to two and on Sundays, only one bulletin was published. During the whole year, there were only three days when BTA was not supposed to publish bulletins: $1^{\text {st }}$ January and the first days of Christmas and Easter. $^{28}$

BTA also published special bulletins that were classified and limited to a small group of people. In 1934, the top secret bulletin named T-4 was published and only four people were supposed to receive this bulletin: The King, Prime Minister, and Director of the Press Office and one for the Archive. This was similar to the bulletin T-3 which was published in the late 1930s for the King, Prime Minister and Archive of the Press Office. However, the T-3 content was the news that was unpleasant for Bulgaria as it was received by radio and published in the press. ${ }^{29}$ In 1935, the Hors bulletin was founded in which unfavorable telegrams concerning Bulgaria were published.

The budget of BTA was difficult to determine because of lack of sources, but it was known that this was part of the budget of the Ministry of Foreign Affairs and Religions. The ministry was, of course very cumbersome and complex with 412 employees in 1939 compared with 70 at the BTA. ${ }^{30}$ We can conclude that their payments were significant. Only for 1939 more than 2 million levas were allocated for the BTA payroll while top clerks received 5,810 monthly or around 70,000 per year. ${ }^{31}$

At this point, we will examine the structure of the Avala during the period under review. The structure of the agency during the late 1930 s consisted of the headquarters in Belgrade and special bureaus in Zagreb, Ljubljana and Novi Sad. For a clearer picture, see the illustration below:

27 Централен дьржавен исторически архив [State's Central Historical Archive], (CDA), 325-1-162, Вьнутрешен правилник на Дирекция на печата [Internal Manual of the Office for the Press], Article 21.

28 Ibid, Article 25.

29100 години Бьгарска телеграфска агенция [100 Years of Bulgarian Telegraph Agency], (Sofia, 1998), without page numbers.

30 Статистически годишнак на Бьлгарското Царство 1939 [Annual Statistical Survey on Bulgarian Kingdome 1939], (Sofia, 1937-1940), p. 640.

31 Budget for 1939, p. 11. 
Avala Personnel at the beginning of $1938^{32}$

HEADQUARTERS (BELGRADE)

Director

Editor in chief

1

Editors

4

Acting editors

2

Chief of sections

1

Relocated correspondents 2

Acting chief of services 1

Secretary

Associates

Treasurer

Administrative clerks

Typists

Radio telegraphers

Chief of personal

Additional personal

22

Cleaning stuff

Total

87

\section{ZAGREB}

Editor in chief 1

Associates 2

Clerk 1

Typists 2

Radio telegraphers 4

Additional personal 5

Total 15

LJUBLJANA

Acting editor in chief 1

Associates 1

32 Годишњи извештај Управног одбора Агенције „Авала" А.Д. о раду у 1937. години [Annual Report of Governing Body of Avala Agency A.D on the work in 1937], (Belgrade, 1938), pp. 123-124. 
$\begin{array}{ll}\text { Clerks } & 1 \\ \text { Typist } & 1 \\ \text { Radio telegraphers } & 3 \\ \text { Additional personal } & 1 \\ \text { Total } & 8\end{array}$

NOVI SAD

Editor in chief 1

Associate 1

Clerks 1

Typist 1

Radio telegraphers 2

Additional personal 1

Total 7

CORRESPONDENTS FROM ABROAD

Correspondent from Tirana 1

TOTAL 118

From the above table, one could see that 87 of the employees (74\%) were based at the headquarters in Belgrade. One could also conclude that the agencies outposts were the only services at specific locations. In different areas of the country, these outposts also had different responsibilities. Having been only responsible for the territory of the Drava Banovina, the section in Ljubljana published and delivered all of its material in Slovenian. This was due to a fact that all the leading newspapers in Slovenia were published in that language. ${ }^{33}$

In Novi Sad, the city with the largest number of newspapers in languages of minorities, its section had specific duties and responsibilities. The city was the capital of the Danube Banovina where six daily newspapers in languages of minorities were published and this gave this Avala section a special, "national and promotional" mission. Agency staff noted that the developed minority press often delivered news from foreign sources in the absence of domestic information. This was not in the interest of the government so an effort was made to upgrade the work of Novi Sad's Avala section. This progress could

${ }^{33}$ Ljubljana had four daily newspapers in Slovenian: Jutro (Morning), Slovenec (Slovenian), Slovenski dom (Slovenian Home) and Slovenski narod (Slovenian Folk). 
be illustrated by the fact that the quality of reporting operations in 1935 was deemed to be "primitive", but in 1937, this service had been deemed in every way to have reached the "required standard". ${ }^{34}$ In total, the bureau had only nine subscribers, of which five were minority press (three Hungarian and two German), one was a newspaper in Serbian, Dan and three government institutions.

The difference in organization between the Yugoslav and Bulgarian institutions was reflected by the fact that the correspondents of the Press Office were at the same time correspondents of BTA, whereas the Avala agency had its own correspondents. Nevertheless, the number of these correspondents was reduced and, after a period of time, the majority of the remaining ones were, after all, those of the CPB. ${ }^{35}$

In the late 1930s, several correspondents from abroad were withdrawn due to financial reasons and correspondents from Paris, Vienna and Sofia were also withdrawn during 1937. As can be seen, the only remaining foreign correspondent was left in Tirana, the capital of Albania, which could be linked to some suggestions made by the CPB correspondent. ${ }^{36}$

As the Bulgarian counterpart, Avala only delivered its classified newsletter to those people approved by the government. In the late 1930s, that decision was made by the Prime Minister Milan Stojadinović (1935-1939) and from one document, we could see that Stojadinović gave a list of names to the president of the Supervisory Board Stijepo Kobasica. The list shows what institutions and people the Prime Minister considered crucial for the functioning of the state. They were regents, several ministers and chiefs of staff, plus representatives of the General Staff and the CPB. ${ }^{37}$ It should be noted that among them were four military officers - Chief of the General Staff, the King's aide, Chief of Intelligence Department and Head of the Operational Department. It is interesting to see that the classified bulletins were delivered to both Stojadinović's heads of cabinets.

34 Годишњи извештај Управног одбора Агенције „Авала" А.Д. о раду у 1937. години [Annual Report of Governing Body of the Avala Agency A.D for the year 1937], (Belgrade, 1938), p. 73.

35 Ibid, p. 34.

36 AY, 38-22. CPB correspondent from Tirana made several suggestions about the necessity that Avala must attempt to achieve the broadest influence in Albania and to counterpart rising Italian influence.

37 The list has 17 names. 
The structure of the Polish agency was more complex than the previous two mentioned agencies and during the 1930s, PAT consisted of the following parts:

1) Information Office

2) Publication Office

3) Advertisement Office

4) Film Office

5) Film Institute

6) Printing Headquarters

7) State Printing

8) P.A.T. branches

Informing the Polish society about all kinds of manifestations of political, social, economic and cultural life, both at home and abroad, and providing overseas news to whole of Poland was the main goal of the Agency. All that was mainly the task of the Information Office.

The Information Office of PAT provided the following services:

1) Information for the daily press;

2) Information for foreign agencies and PAT's correspondents;

3) Information for public authorities;

4) Illustration of publications;

5) Information for the Polish ships at sea (Patoceana). ${ }^{38}$

The main preoccupation of other offices is clear just by looking their names. Among other duties, they had the task to provide funds to cover the operating expenses of providing the relevant information.

The main objective of PAT was to maintain the level and range of information "from the Government's point of view and the interests of the State" ( $w$ myśl wskazań Rządu i interesu Państwa). ${ }^{39}$ The influence of information provided by PAT was significant and important for state propaganda. In order to achieve the aforementioned tasks, PAT needed a huge number of subscribers and clients. Among the subscribers during the 1930s, PAT had more than hundred daily newspapers with an increasing trend: 106 in 1935 and 113 in 1936. ${ }^{40}$

The annual efforts of the agency resulted in increased business and the statistics below illustrated the increase in the amount of information sent to the press in the mid thirties:

\footnotetext{
38 AAN, 8-21II, p. 7.

39 AAN, 8-21II, p. 2.

40 AAN, 8-21II, p. 7.
} 
The Information Sent to the Press by Information Office ${ }^{41}$

\begin{tabular}{|l|r|r|r|}
\hline \multicolumn{1}{|c|}{ YEAR } & \multicolumn{1}{|c|}{1934} & \multicolumn{1}{c|}{1935} & \multicolumn{1}{c|}{1936} \\
\hline NEWS (daily) & 200 & 210 & 230 \\
\hline NEWS (annual) & 73,000 & 76,460 & 81,000 \\
\hline WORDS (daily) & 20,200 & 22,900 & 26,000 \\
\hline WORDS (annual) & $7,300,000$ & $8,400,000$ & $9,100,000$ \\
\hline
\end{tabular}

As it can be seen, the slow but constant increase of work was apparent and this progress was vital for state propaganda efforts of PAT. The position of the agency as the state agency guaranteed that the news was government approved.

Besides the daily news bulletins, the Polish Telegraph Agency had several special regular publications. In 1936, those publications included the following items:

1) Monitor Polski (Polish Monitor) - Polish Republic Journal;

2) Zbiòr Wyrokòw najwyższego Trybunału Administracyjnego (Reports of Judgments of the Administrative Supreme Court) - a quarterly;

3) Gazeta Lwowska (Lvov Journal) - daily;

4) Biuletyn Gieldowy (Bulletin of the Stock Exchange) - daily;

5) Wiadomości Porty Gdyńskiego (the Gdynia Port News) - a monthly, the authority of the Maritime Office in Gdansk;

6) Rocznik Polityczno-Gospodarczy (Political-Economic Yearbook);

7) Special Releases: Arcade, list of State offices and institutions, etc.

The aforementioned publications had different public and propaganda significance for the state propaganda. Probably the most important was Monitor Polski (Polish Monitor) which was established in 1918 as the official legislative paper of the new Second Polish Republic. ${ }^{42}$

\footnotetext{
${ }^{41}$ Ibid.

42 From September to December 1939, the government section was published in exile in France. The Gazette was resumed in 1945 and since 1950, it had been published by the office of the Prime Minister (Chairman of the Council of Ministers) to announce legislation of Parliament (Sejm).
} 
At this point, it is interesting to analyze the business results of PAT sections illustrated in the line of the assigned work. The following table from 1936 data illustrated a general business trend:

Profit and losses for the year 1936 (in Polish zlotys)

\begin{tabular}{|l|r|r|r|}
\hline Sections & \multicolumn{1}{c|}{ Outcome } & \multicolumn{1}{c|}{ Income } & \multicolumn{1}{c|}{ Balance } \\
\hline Information Office & $1,689,345.83$ & $917,496.78$ & $-771,849.05$ \\
\hline Publication Office & $849,295.77$ & $1.833,893.65$ & $+984,597.88$ \\
\hline Advertisement Office & $1,693,919.15$ & $2,128,601.59$ & $+434,682.44$ \\
\hline Film Office & $486,776.52$ & $442,419.06$ & $-44,357.46$ \\
\hline Film Institute & $190,976.94$ & $170,553.58$ & $-20,423.36$ \\
\hline Printing Headquarters & $3,777,849.98$ & $3,900,023.42$ & $+122,173.44$ \\
\hline State Printing & $3,170,381.65$ & $3,639,429.41$ & $+469,047.76$ \\
\hline
\end{tabular}

Source: AAN, 8-21II, p. 31

As seen in the table above, the Information Office made the biggest loss, along with the Film Office, but on the other hand, the Publication and Advertisement sections made significant profits for the agency along with the two printing sections. However, the loss made by the Information Office was somewhat excepted due to the nature of their work, which was gathering information from home and abroad.

In the late 1930s, the Polish Telegraph Agency had around 1,000 employees $^{43}$ which was by far the largest number of the three countries under the review. The agency had various correspondents abroad and the most important cities, from the Polish point of view, had permanent correspondents (Berlin, London, Paris, Moscow, Wien, Riga, Rome, Geneva and New York). ${ }^{44}$

The data for 1935 and 1936 shows that the number of correspondents increased from 243 to 248 with an interesting change in the structure as the number of correspondents at home increased by 19 , but the number of correspondents abroad decreased by 14.45 Thus it can be concluded that the regime wanted to concentrate its propaganda efforts more towards the domestic audience.

The job of correspondent was well paid, especially in Poland where the directors monthly received about 1,800 zlotys, deputy

43 Polska Niepodległa [Indipendent Poland], (Warsaw, 2008), p. 521.

44 Waldemar Grabowski offered an incomplete list of cities and correspondents of PAT: Grabowski, Polska Agencja..., pp. 207-221.

45 AAN, 8-21II, p. 6. 
director and chief editor between 1,200 and 1,500 zlotys; editors received 1,000 zlotys. ${ }^{46}$ The foreign correspondents received even more, if they were employees of a fixed place. For example in Berlin, they received between 2,900 to 3,500 zlotys, in Paris they received around 3,000 zlotys and in Moscow, which was obviously considered the "toughest job", from between 3,500 and 4,000 zlotys. ${ }^{47}$

The number of correspondents revealed that PAT was one of the top agencies in Europe during the 1930s with between 150 and 180 correspondents at home and between 70 and 100 abroad. This was equal to or even better than, some of its bigger agency rivals, e.g. one of the most important world agencies Havas had 100 correspondents abroad while German Wolff had only $50 .{ }^{48}$ These statistics illustrated just how seriously the Polish state took propaganda during the period under review.

\section{Comparative perspectives on the agencies}

The news agencies in Poland, Yugoslavia and Bulgaria were, in many ways similar but also significantly different. The Polish Telegraph Agency, Avala Agency and the Bulgarian Telegraph Agency had the same main responsibilities which were to inform the domestic public about events abroad and to inform the foreign public about the situation at home. Those main tasks were no different than the ones that other agencies had performed during this period all over the world. The agencies had an obligation to inform the public at home and abroad "in accordance to the public state interest", make official announcements, import and distribute foreign newspapers and journals. Nevertheless, their most important role was to transmit official information which came from the top of the governing hierarchy so everybody knew that the information released was official and "checked".

The three agencies were different in size, their relationships with the government, their structures, levels of funding and several other none the less important things. BTA, Avala and PAT were formed as governmental institutions with the aim to inform, but propaganda was, beyond any doubt, one of the main responsibilities of the agencies. PAT was considerably better organized than other two agencies.

\footnotetext{
46 Rudzinski, p. 187.

47 Ibid.

48 Rudzinski, p. 185.
} 
Movie making, independent publishing work, wide range of foreign correspondents network, highly functional advertisement offices were all activities linked only to the Polish agency during the 1930s.

The Yugoslav and Bulgarian agencies received an annual donation from the state and in the case of Avala, this donation amounted to 5 million dinars, but this sum was not sufficient. The finances were often not spent purposefully, so Avala, almost constantly, worked with losses. BTA also was totally dependent on state funding and the income generated from subscribers was not enough to match the costs of both the agencies' work.

PAT was the only of the three agencies that was almost selffinanced as the income gained from advertisements and especially from sold publications and movies was significant and important. However, even that income was sometimes insufficient to cover the growing costs of the Polish news agency organization and its well developed business, especially in the late 1930s.

The difference between the three agencies under the examination was maybe best illustrated when one considered the number of employees. With around 1,000 employees, PAT was by far the biggest of the three, almost ten times larger than Avala and more than thirteen times larger than its Bulgarian counterpart. This difference was also apparent when considering the correspondent network so whilst the Yugoslav and Bulgarian agencies had none or few correspondents abroad, PAT had a very highly developed network which was similar to that of a leading global agency.

The most significant difference between the number of employees in the Polish agency on one hand and those in Yugoslavia and Bulgaria can be seen in the Advertisement Office of PAT which employed 75 people, more than in the whole Bulgarian Telegraphic Agency. This difference corresponded with the budgets of the institutions, but also with the quality and quantity of work that was completed.

Judging by the above data, it can be concluded that the Polish Telegraph Agency had a more significant role in state propaganda than the news agencies in Yugoslavia and Bulgaria. PAT had more responsibilities like publishing official data such as books and magazines and making films that were, in the cases of Yugoslavia and Bulgaria, the responsibility of other propaganda institutions. Those assignments were well beyond the common news agency job scope, which only underlined the statement expressed above about the Polish Telegraph 
Agency's propaganda influence and significance for the state organized propaganda in the period under the review.

The three examined agencies suffered different fates at the beginning of the Second World War. The Bulgarian Telegraph Agency remained part of the Ministry of Foreign Affairs, even in Communist Bulgaria until 1951 when it became an independent institution. Under the new regime, BTA continued its propaganda role, maybe even to a greater extent than during the 1930s. Avala Agency formally ceased to exist after the German occupation of Yugoslavia. The announcement of the liquidation was published (for the third time) in the Opštinskim novinama (Municipal Gazette, No. 56, p.4) on 6th June $1941 .{ }^{49}$ After September 1939, PAT operated in exile, initially in Paris and later in London. After the war was over, it functioned as a governmental news agency for the Polish government in exile. In 1991 after the fall of Communism in Eastern Europe, it was symbolically connected with the Polish Press Agency. ${ }^{50}$

49 Драговић, Српска штампа..., р. 380.

50 Polska Niepodległa, p. 521. 


\section{Резиме}

\section{Др Бојан Симић}

\section{Новинске агенције у служби државне пропаганде у Пољској, Југославији и Бугарској током тридесетих година XX века}

Кључне речи: новинске агенције, БТА, Агенција Авала, ПАТ, Пољска, Југославија, Бугарска, пропаганда

Новинске агенције су играле важну улогу у државној пропаганди европских земаља током тридесетих година XX века. Оне су биле државне, полузваничне и приватне. Њихова главна дужност је била да информишу домаћу јавност о догађајима у иностранству и страну публику о догађајима у матичној земљи. У првом периоду свога рада, након Првог светског рата, централне новинске агенције у Бугарској (Бугарска телеграфска агенција, БТА), Југославији (Агенција Авала) и Пољској (Пољска телеграфска агенција, ПАТ) биле су у државном власништву и функционисале у складу са „вољом владе и интересом државе". Иако су агенције мењале структуру, па се чак и трансформисале у акционарска друштва (Авала), њихова основна функција и веза са државом није се мењала.

Новинске агенције у Бугарској, Југославији и Пољској су биле сличне по настанку и основним функцијама, али и различите по величини и структури. Све три агенције су примале значајне донације од својих влада, а једина која је имала знатну сопствену зараду била је пољска агенција. ПАТ је имао високе приходе од реклама, продатих публикација и снимљених филмова. И поред тога, све три агенције су пословале са већим или мањим губитком. Са око хиљаду запослених ПАТ је био далеко најбројнија организација, десет пута већа од Авале и више од тринест пута већа од БТА. Разлика између агенција посебно се огледала у мрежи кореспондената. Док је пољска агенција имала разгранату мрежу по целој Европи, па и свету, остале две агенције су имале свега неколико дописника ван матичне државе. Без обзира на бројне недостатке у раду и организацији, новинске агенције Бугарске, 
Bojan SIMIĆ, Ph. D.

NEWS AGENCIES IN THE SERVICE OF STATE PROPAGANDA IN POLAND, YUGOSLAVIA AND BULGARIA DURING THE 1930s

Југославије и Пољске су имале велики значај за државну пропаганду у међуратном периоду. 